\title{
石垣築石部の長期荷重時崩壊挙動に関する模型実験 MODEL TESTS ON COLLAPSE BEHAVIOR OF MASONRY WALLS, "TSUKIISHIBU", UNDER LONG-TERM LOAD
}

\author{
桝井 健*，八尾 眞太郎** \\ Takeshi MASUI and Shintaro YAO
}

\begin{abstract}
Model tests were performed in order to obtain collapse behavior of TSUKIISHIBU section in masonry walls under long-term load; the TSUKIISHIBU section represents the whole part of the masonry wall structure excluding corner. A wall model was constructed by rectangular prism shaped masonry stones placed one on another with initial angle of slope on dry sand backfill, and the angle of slope was increased quasi-statically until the model collapses. It is observed that when the initial angle of slope is steep the model collapses with overturning mode of the wall and when the initial angle of slope is relatively mild the model collapses as if the wall was bending at the middle height. As wall heights that the model collapse show good agreement with critical slope curves those are theoretically obtained, validity of the theory for predicting critical height of the wall is clarified.
\end{abstract}

Keywords : masonry wall, stability, critical failure mechanism, model test 石垣、安定性、崩壊機構、模型実験

\section{1.はじめに}

文化財としての城石垣は伝統技術によって構筑されており ${ }^{1 \sim 3)}$ 、 その修復は、伝統技術によってなされるのを原則とする一方で、 建築基準法に基づいて現代科学技術によって評価されることが 義務付けられている。しかし伝統技術を現代科学技術に基づいて 評価することが困難であるために、伝統技術が過小評価されたり、 安全上的確性を欠く修復工事がなされることもあるのが現状で ある。従って、伝統技術を現代科学技術によって解明することお よび両者の技術に整合性を見出すことは重要であり、これまでい くつかの力学的検討がなされてきている ${ }^{4 \sim 6)}$ 。

筆者らは、石垣の修復・設計に必要な知見を得ることを目的と し文献 7）において、石垣の安定と破壊に関する全体的なメカニ ズムについての検討を行った。文献 7）では、石垣の長期荷重時 における崩壊機構を仮定し、これに基づいた石垣の限界方程式を 誘導した。また、それらを解くことによって石垣の限界公配曲線 を導出するとともに、安全率を定義することができた。また、石 垣の反り曲線がもつ力学的な意味を明らかにすることができた。 限界方程式の誘導の基本となる概念は、背面土の塑性すべりによ るクーロン土圧の作用下における石垣石の釣合によるものであ る。既往の研究 ${ }^{4 \sim 5)}$ では、石垣石の転倒に関わる力の釣合を取 り扱うにとどまっており、文献 8) では石垣石のせん断すべりに ついて別途検討することとなっている。限界方程式は、石垣石の 転倒と石垣石のせん断すべりの両者を石垣の崩壊機構として統
一的に取り扱っている点が特徵である。

しかし、それぞれの崩壊機構の発生は、力学的推察による仮定 に基づくものであり、実証的な根拠に基づくものではなかった。 そこで本論では、文献 7）において仮定した崩壊機構およびそ れに基づいて導出された限界勾配曲線の妥当性を確認すること を目的として、長期荷重時における石垣の崩壊挙動に関する模型 実験を実施した結果について報告する。

\section{2. 直線勾配を有する石垣の限界方程式}

直線勾配を有する石垣の限界方程式 ${ }^{7)}$ について以下に示す。石 垣は平面的に見て直線部分である築石部を対象として、その安定 問題を石垣石で覆われた斜面の平面問題として取り扱う。背面土 は砂質土として粘着力 $C=0$ とする。

図 1 に、石垣断面を高さ $H$ で切断した解析モデルを示す。石 垣は、水平面と $\theta$ の角をなす直線斜面上に構築されており石垣底 面幅は $L$ である。背面土には水平面と $\omega$ の角をなす塑性すべりが 発生している場合を想定する。また、本論では、背面土の地表面 傾斜角 $i$ を考慮する。

土楔 $\triangle A B C$ が塑性すべりを起こすときの鈎合条件から得られ るいわゆるクーロンの主働土圧合力は式(1)である。

$$
P_{a}=\frac{1}{2} \gamma H^{2} K_{a}
$$

ここに、 $\gamma$ は背面土の単位体積重量である。また、 $K_{a}$ はクー

\footnotetext{
本論文の一部は文献9)において発表済みである。

関西大学環境都市工学部建築学科 准教授 ·博士 (工学)
}

** 関西大学環境都市工学部建築学科 教授 $\cdot$ 工博
Assoc. Prof., Dept. of Architecture, Faculty of Environmental and Urban Engineering, Kansai Univ., Dr. Eng.

Prof., Dept. of Architecture, Faculty of Environmental and Urban Engineering, Kansai Univ., Dr. Eng. 


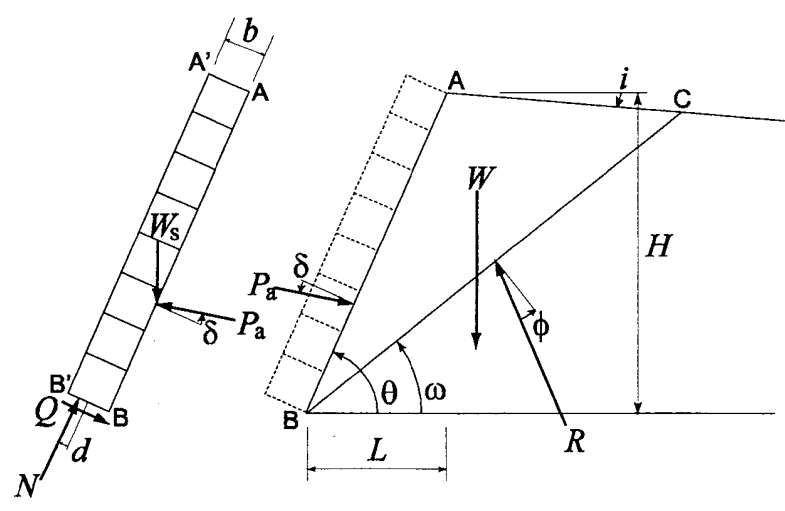

図 1 解析モデル

ロンの主㗢土圧係数であり、式(2)により与えられる。

$$
K_{a}=\frac{\sin ^{2}(\theta-\phi)}{\sin ^{2} \theta \sin (\theta+\delta)\left\{1+\sqrt{\frac{\sin (\delta+\phi) \sin (\phi+i)}{\sin (\theta+\delta) \sin (\theta+i)}}\right\}^{2}}
$$

ここに、 $\phi, \delta$ は、背面土の内部摩擦角、背面土と石垣石の摩擦角 をそれぞれ表す。

石垣の崩壊機構が、石垣石間のせん断すべりで定まる場合、軸 方向力 $N$ とせん断力 $Q$ との間には次の塑性条件式が成立する。

$$
Q=N \tan \phi_{S}
$$

ここに、 $\phi_{s}$ は石垣石同士の摩擦角を表す。

石垣石の崩壊機構が、転倒モーメントで定まる場合の条件式は、 軸方向力 $N$ の偏心距離 $d$ がある基準值に達した場合として、石 垣石の幅（控え長さ） $b$ に対する比率 $\alpha$ を用いて次式のように表 される。

$$
d=\alpha b
$$

ここで、次式で定義される無次元量を導入する。

$$
\bar{H}=\frac{H}{b}, \bar{L}=\frac{L}{b}, \bar{d}=\frac{d}{b}, \bar{\gamma}=\frac{\gamma_{s}}{\gamma}
$$

ここに、 $\gamma_{s}$ は石垣石の単位体積重量を表す。

全体の釣合式および式(3)，(4)，(5)に基づき、無次元量により 表される限界方程式は以下のように得られる。

せん断すべりによる限界方程式

$$
\vec{H}-\frac{2 \bar{\gamma} \cos \left(\theta-\phi_{s}\right)}{K_{a} \sin \theta \cos \left(\delta+\phi_{s}\right)}=0
$$

転倒モーメントによる限界方程式

$$
\frac{K_{a} \cos \delta}{6 \sin \theta} \bar{H}^{2}-\left\{\frac{K_{a}(2 \alpha+1) \sin \delta}{4}+\frac{\bar{\gamma} \cos \theta}{2 \sin ^{2} \theta}\right\} \bar{H}-\alpha \bar{\gamma}=0
$$

\section{3. 限界勾配曲線}

図 2 に限界勾配曲線の模式図を示す。同図の縌座標は $\bar{H}$ であ り横座標は $\bar{L}$ である。点 $\mathrm{A}_{1}$ は、背面土の内部摩擦角が $\phi=\phi_{1}$ で あり勾配が $\theta_{\mathrm{A}_{1}}$ である石垣についての計算結果を示しており、 $\bar{H}_{c r}=\bar{H}_{\mathrm{A}}$ および $\bar{L}_{c r}=\bar{L}_{\mathrm{A}_{1}}$ で、この石垣は崩壊機構となることを 示している。点 $A_{1}$ と原点 $O$ を結んだ直線 $O A_{1}$ は、背面土の内部 摩擦角が $\phi=\phi_{1}$ で崩壊機構となる石垣の直線斜面を表している。

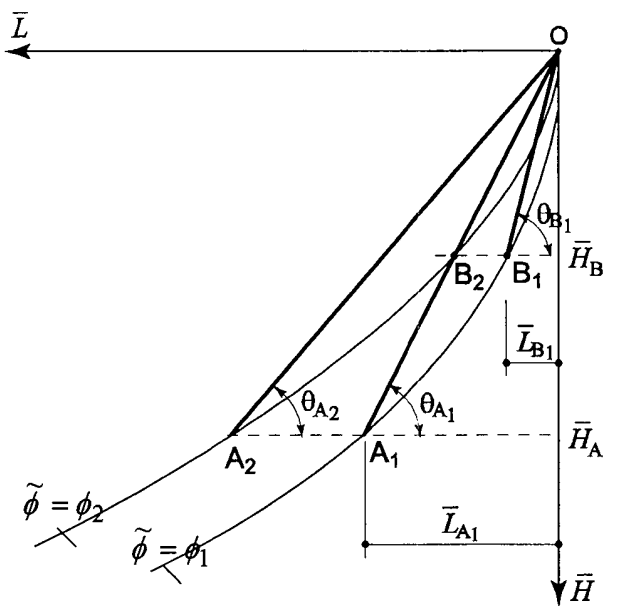

図 2 限界勾配曲線の模式図

同様に、背面土の内部摩擦角が $\phi=\phi_{1}$ であり勾配が $\theta_{\mathrm{B}_{1}}$ である石 垣についても、計算結果 $\bar{H}_{c r}=\bar{H}_{\mathrm{B}}$ および $\bar{L}_{c r}=\bar{L}_{\mathrm{B}_{1}}$ を点 $\mathrm{B}_{1}$ とし て得ることができる。このように、背面土の内部摩摖角 $\phi$ が一定 の值 $\phi_{1}$ である場合に、崩壊機構を表す点 $\left(\bar{H}_{c r}, \bar{L}_{c r}\right)$ の軌跡は一本 の曲線を描く。この曲線を限界勾配曲線と称する。いわゆる支力 線 ${ }^{4)}$ とは異なり、限界勾配曲線は一般に原点を通る曲線とはなら ない。

石垣背面土の土質定数としての $\phi$ と区別する為に限界勾配曲

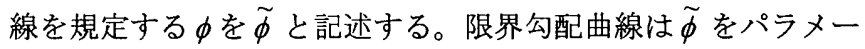
ターとして曲線群を形成する。曲線群において左へ移動するほど $\widetilde{\phi}$ の值は小さくなる。

背面土の内部摩擦角が $\phi=\phi_{1}$ であるとき石垣の斜面 $O_{1}$ より もゆるい勾配例えば $O A_{2}$ である場合には石垣は弾性状態にあっ て安定であることを示している。OA 2 の勾配は $\phi=\phi_{2}<\phi_{1}$ で崩壊 機構となることを示している。逆に背面土の内部摩擦角が $\phi=\phi_{1}$ であるとき $\mathrm{OA}_{1}$ よりも急な斜面の場合には石垣は不安定である ことがわかる。

また、図 2 において、無次元化石垣高さが $\bar{H}_{\mathrm{B}}$ のように $\bar{H}_{\mathrm{A}}$ よ りも低くなった場合、勾配 $\mathrm{OB}_{2}$ である石垣は $\phi=\phi_{2}$ で崩壊機構 となり、 $\phi=\phi_{1}$ の時には弾性状態であるので同じ内部摩擦角の場 合には石垣高さが低くなれば石垣の安定性が増大することを示 している。

\section{4. 石垣模型の予備崩壊実験 \\ 4. 1 実験概要}

限界方程式の導出の根拠となる石垣の崩壊機構は仮定したも のであり、その妥当性を確認する必要がある。ここでは、石坦模 型による長期荷重時の予備崩壊実験を実施した結果について述 ベる。

背面土には淀川砂を用いた。背面土の単位体積重量は、崩壊実 験のときと同様である乾燥状態での重量堆積時の相対密度 $30 \%$ となるようにして計測し $\gamma=1.44 \mathrm{~g} / \mathrm{cm}^{3}$ を得た。内部摩擦角は、相 対密度 $30 \%$ で拘束圧 $50,100,200,300 \mathrm{kPa}$ とした 4 回の三軸圧縮試 験結果の平均値として $\phi=34.7^{\circ}$ を得た。 


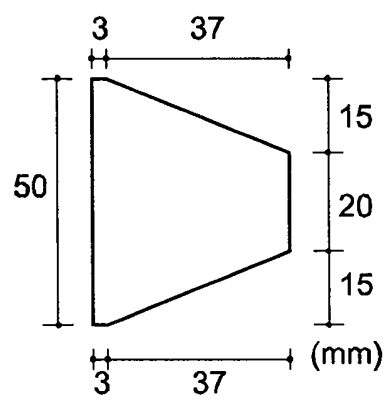

（a）実験に用いた形状

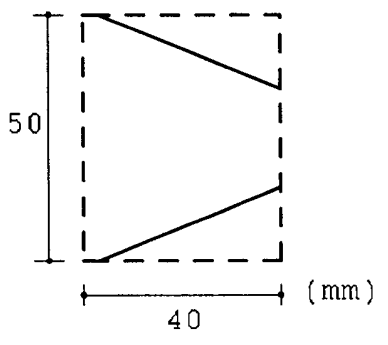

（b）解析で考慮する領域

\section{図 3 石垣石断面形状}

石垣石は兵庫県高砂市産の竜山石（水中粉砕された流紋岩の堆 積岩）を切削して製作した。石垣石の単位体積重量は、 $\gamma_{s}=2.27 \mathrm{~g} / \mathrm{cm}^{3}$ である。石垣石は図 3 に示す断面形状を持つ長さ $100 \mathrm{~m}$ mの柱体である。石垣石断面の形状は、実際の石垣石の形 状を参考として、図 3(a)に示すようなものとし、石垣石同士は幅 $3 \mathrm{~mm}$ の部分でのみ接触するようにした ${ }^{10\rangle}$ 。石垣石間の楔状の空間 には背面土を充填する。これにより、石垣石間にずれが発生する とほぼ同時に石垣の崩壊に至るので、崩壊判定が容易に行える。 解析には図 3(b)の破線で囲んだ領域を石垣石として取り扱うこ ととした。単位体積重量は面積で按分することして、解析には、 $\gamma_{s}=2.04 \mathrm{~g} / \mathrm{cm}^{3}$ を用いることとした。

予備実験に用いた石垣模型を図 4 に示す。背面土は側面三方を アクリルボードで囲まれるようにし、アクリルボードはアルミフ レームによって補剛されている。アクリルボードと背面土の間に は2層のテフロンシートが挟んであり、摩擦を極力なくしている。

\section{2 実験結果}

石垣の傾斜角 $\theta$ として、 $77^{\circ}$ から $1^{\circ}$ ごとの増分で $85^{\circ}$ までの 計 9 種類を設定し、それぞれの傾斜角ごとに実験を 2 回ずつ実施 した。

実験の結果、いずれの傾斜角の場合においても最下端の石垣石 のすべりが生じることにより、石垣は崩壊に至ることが確認され た。石垣の傾斜角と崩壊時の石垣の段数 $n$ の関係を表 1 に示す。

表 1 石垣傾斜角と崩壊時の石垣段数の関係

\begin{tabular}{|c|c|c|}
\hline \multirow{2}{*}{$\begin{array}{c}\text { 傾斜角 } \theta \\
\left({ }^{\circ}\right)\end{array}$} & \multicolumn{2}{|c|}{ 崩壊時の石垣段数 $n$} \\
\hline 77 & 1 回目 & 2 回目 \\
\hline 78 & 14 & 14 \\
\hline 79 & 13 & 13 \\
\hline 80 & 13 & 13 \\
\hline 81 & 12 & 12 \\
\hline 82 & 12 & 12 \\
\hline 83 & 10 & 10 \\
\hline 84 & 10 & 10 \\
\hline 85 & 9 & 10 \\
\hline
\end{tabular}

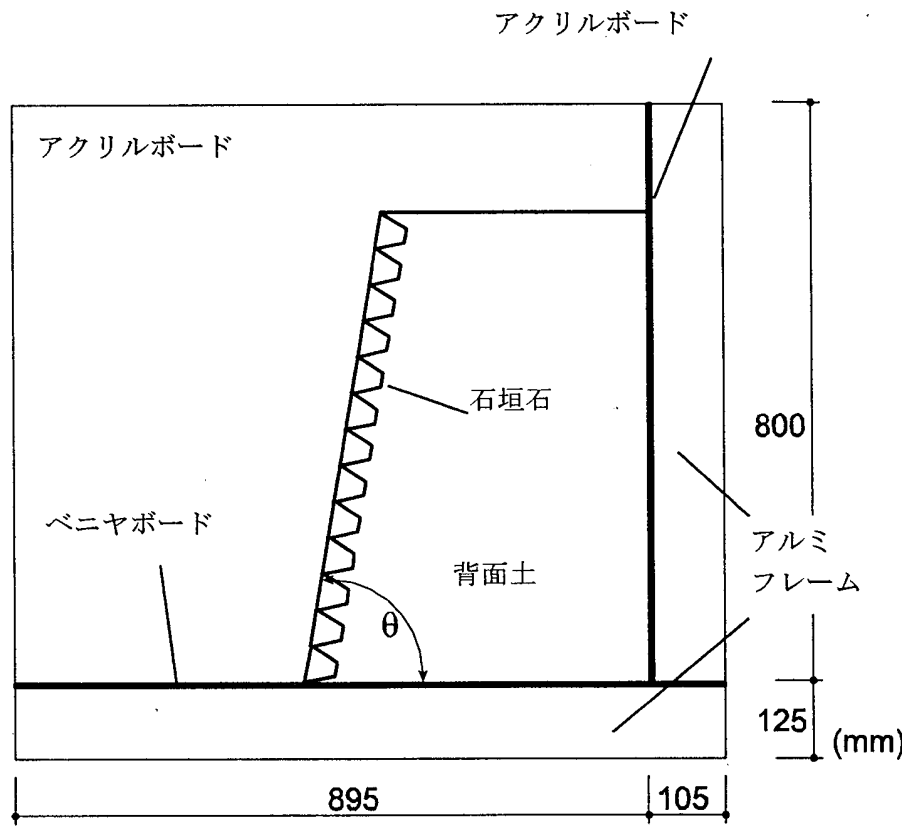

図 4 予備実験装置

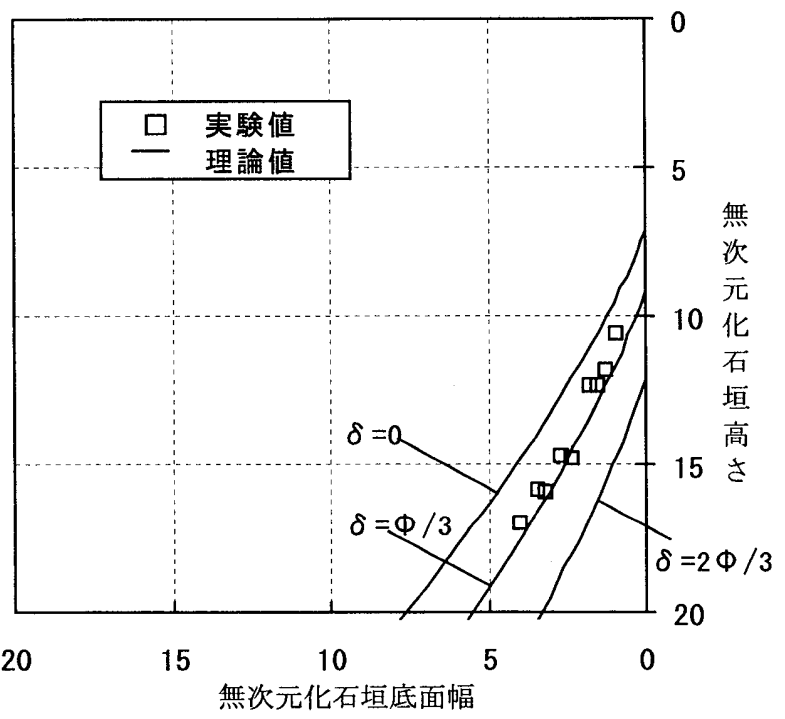

図 5 実験結果と限界勾配曲線の比較

ただし、崩壊は最上段の石垣の製作中に発生するなどして、崩 壊時の石垣段数 $n$ の厳密な測定は困難であった。また、崩壊時の 石垣高さ $H_{c r}$ および石垣底面幅 $L_{c r}$ は計測できていない。そこで、 $H_{c r}$ および $L_{c r}$ については、石垣石の高さ $h=50 \mathrm{~mm}$ であるので、 $H_{c r}=n \times h \cdot \sin \theta$ および $L_{c r}=n \times h \cdot \cos \theta$ より概算した。

それぞれの傾斜角の実験結果として、2 回の実験結果の平均值 を用い、 $H_{c r}$ および $L_{c r}$ を求め、 $b$ で無次元化した結果を図 5 に 示す。比較のため、限界方程式から求められる限界勾配曲線をあ わせて示す。石垣石間の摩擦角は不明であるので、背面士の内部 摩擦角と同じ值の $\phi_{S}=34.7^{\circ}$ と仮定した。石垣石と背面土との摩 擦角も不明であり、かつすべりは砂と石および砂の混じった領域 で発生するので、 $\delta=0, \delta=\phi / 3$ および $\delta=2 \phi / 3$ の場合について 求めた。実験結果は、 $\delta=\phi / 3$ に対応する限界勾配曲線にほぼ一 致することがわかる。 


\section{3 予備実験に関する考察}

予備実験によって得られた知見および問題点は、以下のように まとめられる。

1）石垣の崩壊形式は、理論解析で仮定したものと整合している ようである。

2）実験結果と限界勾配曲線はほぼ整合する。

3）石垣を下から順に製作していくため、石垣の崩壊が製作途中 に発生するなどして、崩壊の瞬間を厳密にとらえることができて いない。

4) 同様に、崩壊時における背面土のすべりの様子もとらえられ ていない。そのため、背面土が、発生するすべり線が後部のアク リルボードと干渉しないような十分な奥行きを確保できていた のか不明である。

5 ) 石垣石の寸法が比較的大きいため、緩い勾配の石垣では実験 装置の高さ近くまで積み上げてもなお安定していた。そのため、 実験は比較的急勾配の石垣の夕についてしか行えなかった。その ため、緩い勾配については、解析結果との整合性を議論できてい ない。

6 ）石垣石の寸法が比較的大きいため、石垣の製作には長時間を 要した (一回あたり所要時間 8 時間程度)。

7 ) 石垣石同士および石垣石と砂との摩擦角が得られていない。 8 ) 石垣石の断面形状が解析モデルと対応しておらず、石垣石と 石垣石の間にある楔状の砂の部分において砂内部のすべりが発 生していると考えられる。石垣石の断面を長方形とすれば、解析 モデルとの整合を持たせることができる。

\section{5. 小型石垣模型の崩壊実験}

\section{1 実験供試体}

予備実験における問題点を解決し、より正確かつ広範囲の実験 結果を得るために小型石垣模型による崩壊実験を実施すること とした。限界方程式（6)、（7）は、石垣石の幅（控え長さ） $b$ に よって完全に無次元化されているので、実大の石垣との相似則を 考える場合には、bに対応づけて考えればよいことになる。ただ し、背面土の土粒子径には相似則が成立していないことなど、以 下の実験結果をもってただちにこれが実大の石垣の挙動を示し ていると考えてはならないことは言をまたない。

実験供試体は、石垣石および背面土からなる。石垣石は予備実 験と同様に竜山石を用い、背面土には乾燥状態の豊浦標準砂を用 いることとした。解析モデルと同様となるように、石垣石および 背面土を一層ずつ積み上げていき、供試体を製作する。図 6 に示 すように、積み上げる一般部の石垣石は直方体とする。1 段当り、 横幅 $w$ 方向に中央部石垣石を 3 個並べ、側面の摩擦の影響をなく すため、両端には横幅の短い両端部石垣石をそれぞれ 1 個並べる。 間隔の遊び $2 \mathrm{~mm}$ を見込んで石垣の横幅を $210 \mathrm{~mm}$ とする。最下段の 石垣は図7に示すような形状とした。側面の断面は台形状であり、 石垣の設定勾配に対応した角度 $\theta_{s}$ の斜面を設けている。実験時 には最下段の石垣石は実験装置に剛に固定する。一般部の石垣石 はこの斜面上に積み上げていく。

予備実験に比べて石垣石を小さくすることによって、予備実験 と同一の実験装置を用いても、多くの段数の石垣を積むことがで
きるようになったのはもちろんのこと、石垣の積み上げに要する 時間が短縮され（一回あたり所要時間 2 時間程度）、同一条件で 複数回の実験を容易に行えることが可能となった。

石垣石の単位体積重量は $\gamma_{s}=2.34 \mathrm{~g} / \mathrm{cm}^{3}$ と計測された。背面土 の単位体積重量は崩壊実験における平均的な相対密度 $26 \%$ に対 応する值として $\gamma=1.41 \mathrm{~g} / \mathrm{cm}^{3}$ と算定した。背面土の内部摩擦角は、 相対密度 $26 \%$ で拘束圧 $50,100,200 \mathrm{kPa}$ とした 3 回の三軸圧縮試験 結果より $\phi=34.3^{\circ}$ を得た。この拘束圧は、崩壊実験における作用 土圧と比べて大きい。また、崩壊実験は平面ひずみ条件を想定し ているので応力状態も異なっている。しかし、崩壊実験における 応力状態での内部摩擦角を測定することは困難であることや、安 息角の測定を別途行った結果、安息角は三軸圧縮試験結果に基づ く内部摩擦角とほぼ同様の值となっていたことから、以下の検討 では、 $\phi=34.3^{\circ}$ を用いることとする。

石垣石同士および石垣石と砂の摩擦角に関しては標準的な試 験方法がないため、図 8 に示す装置による一面せん断試験を実施 して実験值を測定した。一面せん断試験の結果、 $\phi_{S}=34.5^{\circ} お よ$ び $\delta=30.0^{\circ}$ が得られた。

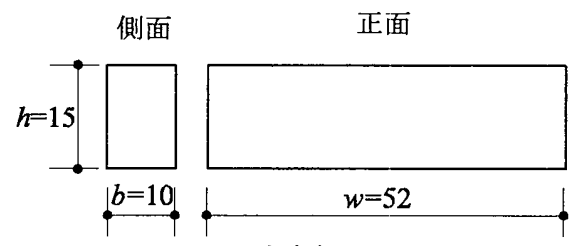

(a)中央部

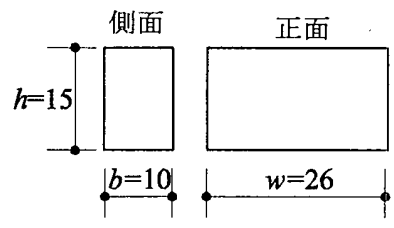

(mm)

(b)両端部

図 6 一般部の石垣石

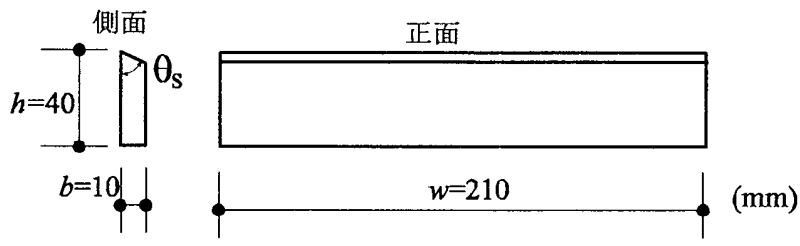

図 7 最下段の石垣石

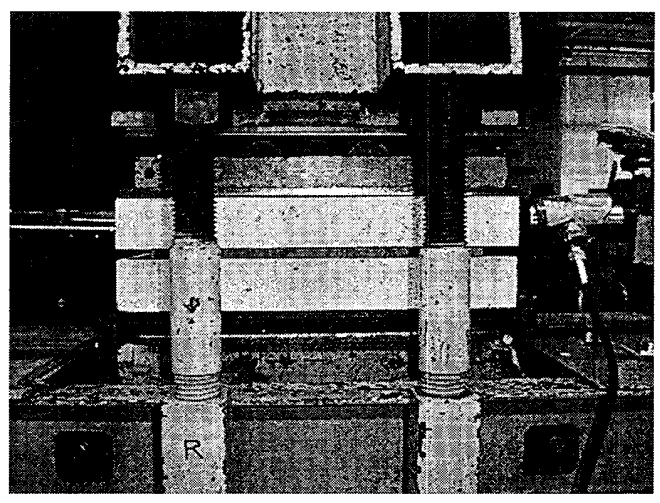

図 8 一面せん断試験装置 


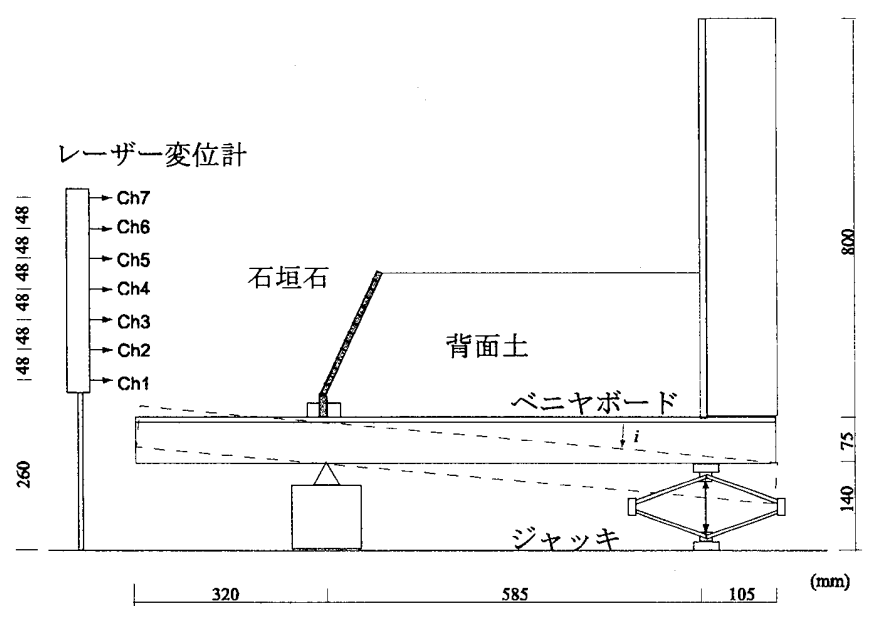

図 9 小型石垣模型実験装置

\section{2 実験方法}

実験装置を図 9 に示す。石垣の両側面はアクリルボードで固定 してあり、背面土には十分な奥行を確保している。実験装置底板 はベニヤボードであり、その下面をアルミ製フレームで補強して あり剛とみなすことができる。石垣崩壊実験は以下の手順で実施 する。

1）設定勾配として $\theta_{S}=70^{\circ}, 75^{\circ}, 80^{\circ}, 85^{\circ}, 90^{\circ}$ の 5 種類を設定し、 それぞれの角度に応じた石垣崩壊段数の予測值を理論式に基づ いて求める。

2) 設定勾配に忘じた最下段の石垣石を実験装置底板に固定する。 従って、最下段の石垣石は実験中も装置に固定されたままであり、 石垣石の崩壊は一般部の石垣のみに発生することとなる。

3）最下段の石垣石底面を通る軸を中心軸として、石垣の勾配が 緩くなる方向（安全側）に実験装置全体を水平面から $i=5^{\circ}$ 傾斜 させる。従って、石垣の初期勾配は $\theta_{0}=\theta_{s}-5^{\circ}$ となる。

4) 実験装置底板と平行になるように石垣高さまで背面土を盛る。

5 ）一般部の石垣石を石垣石高さ $h$ 方向に 1 段積み上げ、4) を 繰り返し、一般部の石垣段数が石垣崩壊段数予測值となるまで、 この手順を繰り返す。

6 ）淮静的に（1/分）実験装置傾斜角をジャッキによって減少 させる。

7 ) 石垣崩壊時の実験装置底板の水平面からの傾斜角を $0.5^{\circ}$ 単位 で測定し、崩壊時の石垣勾配 $\theta_{c r}$ を求める。

$8 ）$ 実験装置傾斜角の減少分が $9^{\circ}$ を超えて、なお崩壊が発生し ない場合は、石垣崩壊段数予測值を 1 増加させて、2）からの手 順を繰り返す。石垣崩壊時の崩壊モードを把握するため、石垣石 の水平変位をレーザー変位計によって測定する。底面より $45 \mathrm{~mm}$ の高さを $\mathrm{Ch} 1$ として高さ $48 \mathrm{~mm}$ 間隔で $\mathrm{Ch} 7$ まで測定する。さら に、石垣崩壊時の崩壊形状を捉えるためにビデオ撮影を行う。

\section{3 実験結果}

（a）限界勾配について

実験結果として、崩壊時の石垣勾配 $\theta_{c r}$ と石垣段数 $n$ の関係を 表 2 に示す。崩壊時の石垣勾配 $\theta_{c r}$ と石垣段数 $n$ とから $\bar{H}_{c r}$ およ び $\bar{L}_{c r}$ を求めることができる。 $\bar{H}, \bar{L}$ 平面上にそれぞれの赛験時に

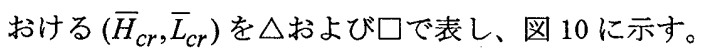

表 2 崩壊時の石垣勾配と石垣段数の関係

\begin{tabular}{|c|c|c|c|}
\hline \multirow[b]{2}{*}{$\begin{array}{c}\text { 初期勾配 } \\
\left.\theta_{0} \quad{ }^{\circ}{ }^{\circ}\right)\end{array}$} & \multicolumn{3}{|c|}{ 崩壊時 } \\
\hline & $\begin{array}{l}\text { 石垣勾配 } \\
\theta_{c r}\left(^{\circ}\right)\end{array}$ & $\begin{array}{l}\text { 装置 } \\
\text { 傾斜角 } \\
\left.i^{\circ}{ }^{\circ}\right)\end{array}$ & $\begin{array}{c}\text { 石垣段数 } \\
n\end{array}$ \\
\hline \multirow{3}{*}{85.0} & 89.0 & 1.0 & 5 \\
\hline & 88.5 & 1.5 & 5 \\
\hline & 88.0 & 2.0 & 5 \\
\hline \multirow{2}{*}{80.0} & 83.0 & 2.0 & 6 \\
\hline & 83.0 & 2.0 & 7 \\
\hline \multirow{4}{*}{75.0} & 80.0 & 0.0 & 9 \\
\hline & 80.0 & 0.0 & 9 \\
\hline & 79.0 & 1.0 & 9 \\
\hline & 79.0 & 1.0 & 9 \\
\hline \multirow{8}{*}{70.0} & 78.5 & -3.5 & 13 \\
\hline & 77.5 & -2.5 & 15 \\
\hline & 76.5 & -1.5 & 17 \\
\hline & 76.0 & -1.0 & 12 \\
\hline & 74.0 & 1.0 & 16 \\
\hline & 73.0 & 2.0 & 14 \\
\hline & 71.0 & 4.0 & 17 \\
\hline & 70.0 & 5.0 & 19 \\
\hline \multirow{4}{*}{65.0} & 73.5 & -3.5 & 21 \\
\hline & 71.0 & -1.0 & 23 \\
\hline & 67.5 & 2.5 & 24 \\
\hline & 66.5 & 3.5 & 25 \\
\hline
\end{tabular}

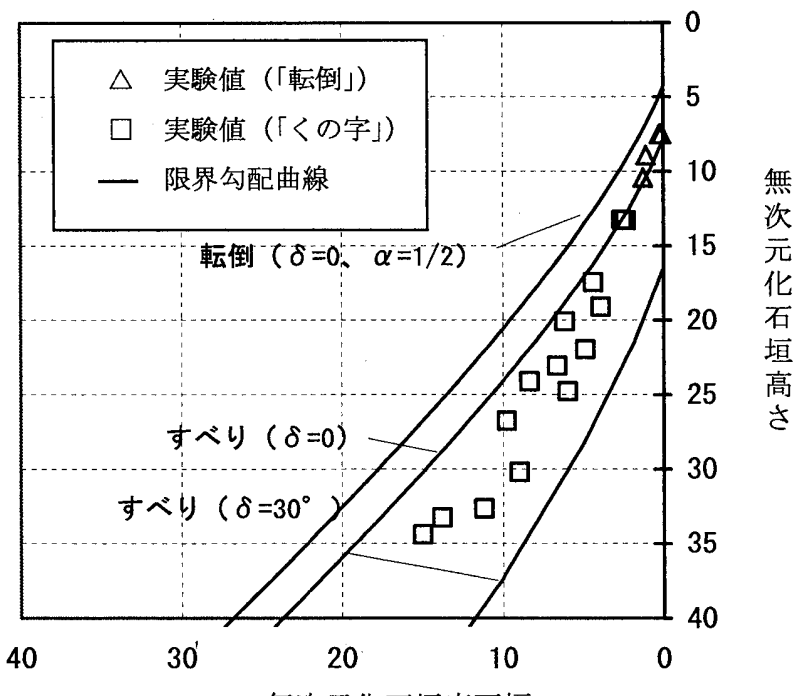

無次元化石垣底面幅

図 10 限界勾配曲線と実験值の比較 $\left(\phi=34.3^{\circ}, \phi_{S}=34.5^{\circ}, i=0^{\circ}\right)$

図 10 には、理論値との比較として、せん断すべりによる場合 は $\delta=0$ と、 $\delta=30^{\circ}$ の限界勾配曲線を示した。転倒モーメントに よる場合は $\delta=0, \alpha=1 / 2$ とした。なお、実験值は種々の装置傾斜 角に対忘しているが、理論值は $i=0^{\circ}$ の場合と $i=5^{\circ}$ の場合との 
差は最大でも $5 \%$ 未満であるので、 $i=0^{\circ}$ として求めた。

(b) 崩壊形状について

石垣崩壊時の変位測定結果およびビデオ撮影結果より、石垣の 崩壊形状は、石垣勾配に応じて 2 種類に分類できた。

1 ）急な石垣勾配の場合

石垣石全体が、底面を通る軸を中心に回転し、一枚の板のよう に転倒するように崩壊する。この崩壊形状は、石垣勾配が $83^{\circ}$ 〜 $89^{\circ}$ の場合に発生した。崩壊時の石坦勾配が $88.5^{\circ}$ のときを例に 崩壊時の写真を図 11 に示す。写真中央付近に写っている縦に並 ぶ 2 つ光点は変位計測位置におけるレーザー光であり、下から 順に Ch1、Ch2 に対応している。また、崩壊時付近 0.5 秒間の石 垣石の変位測定結果を図 12 に示す。石垣石の変位は高さに応じ てほぼ比例的に増大しており、一枚の板のように転倒している樣 子が分かる。(図 10 では、「転倒」として $\triangle て ゙$ 表記。

\section{2 ）緩い石垣勾配の場合}

石垣の中央付近の高さで、横から見ると「くの字」状に石垣石 が崩壊する。この崩壊形状は、石垣勾配が $80^{\circ}$ 以下の場合に発生 した。崩壊時の石垣勾配が $76^{\circ}$ のときを例に、崩壊時の写真を図 13 に示す。図 11 と同様に、写真中央付近に写っている綐に並ぶ 4 つの光点は、下から順に変位計測位置 Ch1 から Ch4 に対応して

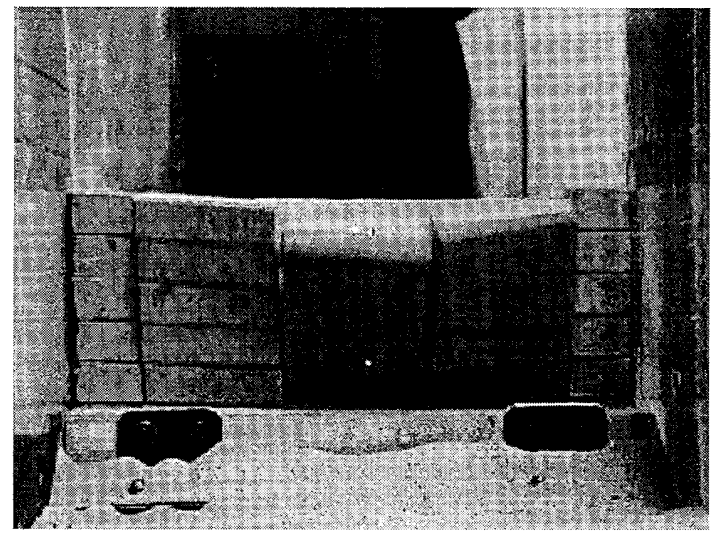

図 11 崩壊の様子（崩壊時石垣勾配: $88.5^{\circ}$ )

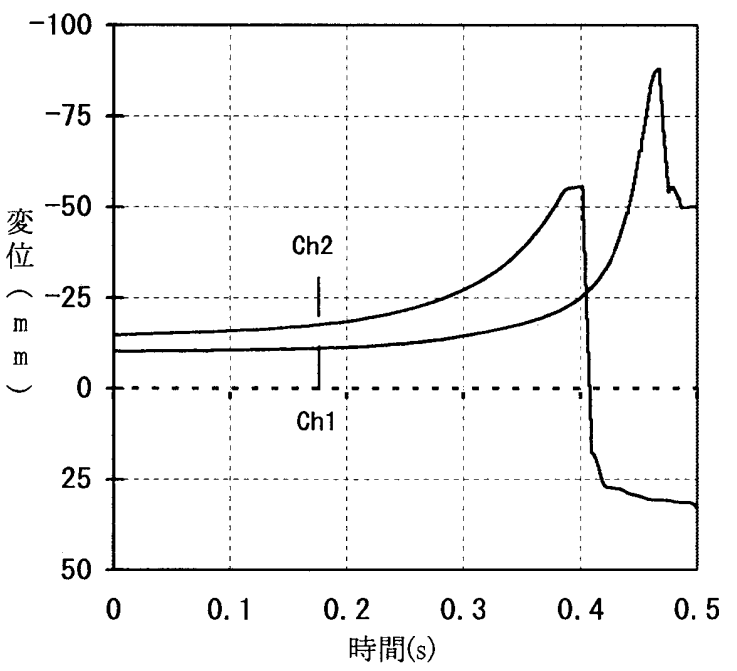

図 12 石垣石の変位測定結果（崩壊時石垣勾配: $88.5^{\circ}$ )
いる。また、崩壊時付近 0.5 秒間の石垣石の変位測定結果を図 14 に示す。中央高さ付近の石垣石の変位が大きく発生している様子 が分かる。（図 10 では、「くの字」としてロで表記。）

\section{4 小型石垣模型実験に関する考察}

実験值と理論值は以下のような考察のもと、良好な対応を示し たものと考えられる。

勾配が急な部分 $\left(\theta_{c r}=83^{\circ} \sim 89^{\circ}\right)$ では、実験結果は、転倒モ 一メントで定まる場合と $\delta=0$ の場合のせん断すべりで定まる限 界勾配曲線の間に分布した。従って、石垣の崩壊は転倒によるも のと考えられるが、転倒のきっかけが石垣石間のせん断すべりで あった可能性も考えられる。その場合は、石垣石に作用している 軸力が非常に小さいため、积よりもわずかに小さい摩擦角で石 垣石間のすべりが発生したものと考えられる。 $\delta=0$ に対応して いることから、石垣石と背面土との間のすべりはほとんど発生し ていなかったことがわかる。

勾配が比較的緩い部分 $\left(\theta_{c r}=66.5^{\circ} \sim 80^{\circ}\right)$ では、実験結果は、 $\delta=0$ と $\delta=30^{\circ}$ のせん断すべりで定まる 2 つの限界勾配曲線で はさまれた領域にほぼおさまる結果となった。この結果には様々 な解釈が考えられる。まず、この領域では、石垣石と背面土との 間にすべりが発生する部分が存在するようになったと考えられ

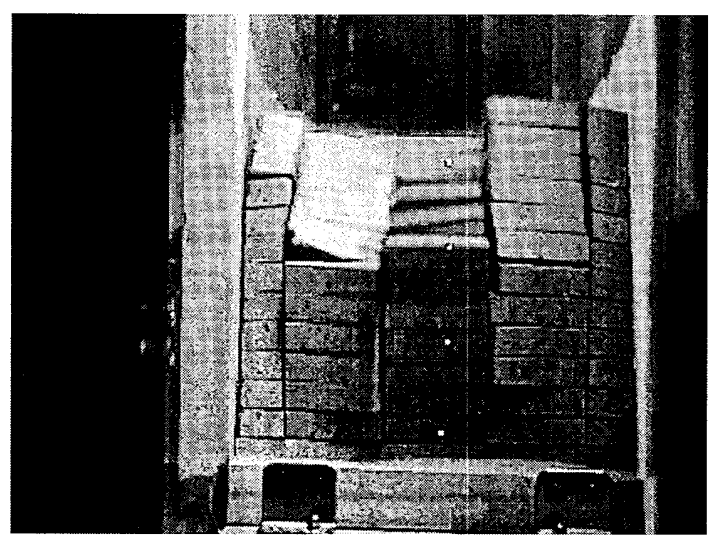

図 13 崩壊の様子（崩壊時石垣勾配: 76. $0^{\circ}$ ）

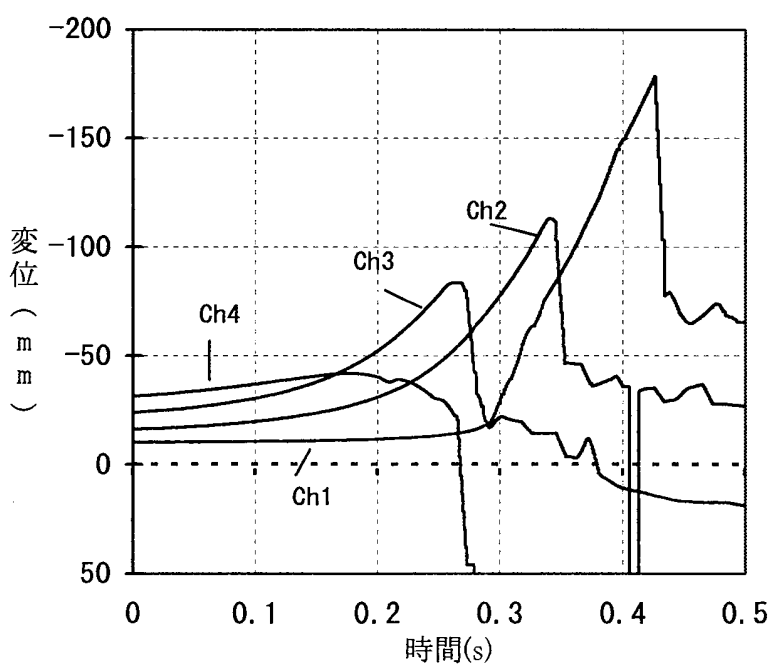

図 14 石垣石の変位測定結果（崩壊時石垣勾配: 76. $0^{\circ}$ ） 
ること、崩壊実験での応力状態が非常に小さいため一面せん断試 験で得られた $\delta=30^{\circ}$ に比べて実際にはやや小さめの值であった のではないかということ、崩壊形状からの類推より、すべりは石 垣上部で発生し、石垣下部では転倒しているためこの部分では $\delta$ は0の状況であったこと等が推測される。このことより、実験結 果は、 $\delta$ の值として 0 から $30^{\circ}$ の間の值をとるものと考えられ、 転倒部分が多いほど結果は $\delta=0$ の曲線に近づく。

以上のように、実験結果と限界勾配曲線の間にはよい対応が確 認され、限界勾配曲線の妥当性が示されたと考えられる。

しかしながら、すべりによる崩壊機構と転倒による崩壊機構の 発生を分ける規準がないことや、実験時のような低拘束圧での土 圧の測定ができていないことに起因して摩擦角等の仮定した值 がどの程度妥当であるかの検証ができていないことなど、今後の 課題である。

\section{6. まとめ}

石垣の崩壊機構およびそれに基づいて導出された限界勾配曲 線の妥当性を確認することを目的として、小型石垣模型の崩壊実 験を実施した。

実験の結果、実験值と理論値にはよい対応が確認され、石垣の
限界勾配曲線の妥当性を確認することができた。

\section{参考文献}

1）喜内敏 監修·解説：「金沢城郭資料一加賀瀋穴生方後藤家文書」、日本海 文化叢書、第 3 巻、石川県図書館協会、1976

2）北垣聰一郎：「石垣普請」法政大学出版局、1987

3）北垣㮩一郎：伝統技術からみた城郭石垣の勾配について、関西大学考古学 研究室開設 50 周年記念考古学論丵、2002.9

4）岡積満：間知石の法勾配 (1)、土木技術 Vol. 5、No. 9, pp11-13, 1950

5）市岡隆興、石井信行、篠原修：伝統的石積技法の力学的考察、構造工学論 文集、Vol. 42A，pp. 519-526，1996

6）西田一彦、西形達明、玉野富雄、森本浩行 : 城郭石垣断面形状の設計法と その数式表示に関する考察、土木学会論文集 No. 750/mI-65, 89-98，2003

7）八尾直太郎、桝井健：石坦築石部の長期荷重時安定性について、日本建築 学会構造系論文集, No. 593, pp81-86, 2005.7

8）右城猛：新・䑾壁の設計法と計算例、第 6 章もたれ式㩲壁、理工図書、1998

9）桝井健、八尾眞太郎：石垣筑石部の長期荷重時安定性に関する小型模型崩 壊実験、日本建築学会大会学術講演梗概集 (関東)、B-1 (構造 I), pp609-610, 2006. 9

10）矽井健、八尾䢐太郎：城石垣の構造安定性に関寸る基礎的研究 一その 1 石坦模型の崩壊実験-、日本建築学会大会学術講演梗概集（関東）、B-1 (構 造 I), pp531-532, 2001.9

（2006年11月10日原稿受理，2007年 5 月18日採用決定） 